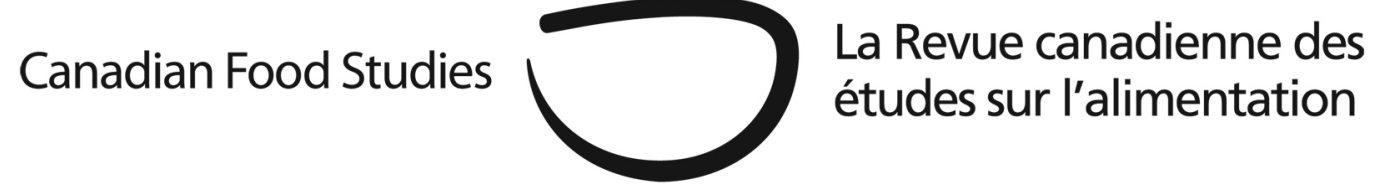

Original Research Article

\title{
Climate change, community capitals, and food security: Building a more sustainable food system in a northern Canadian boreal community
}

\author{
Andrew Spring ${ }^{a^{\star}}$, Blair Carter ${ }^{\mathrm{b}}$, Alison Blay-Palmer ${ }^{\mathrm{a}}$ \\ ${ }^{a}$ Wilfrid Laurier University \\ ${ }^{b}$ Ecology North
}

\begin{abstract}
Canada's North offers unique food systems perspectives. Built on close cultural and spiritual ties to the land, the food systems within many northern communities still rely on the harvesting and gathering of traditional food and function through the sharing of food throughout the community. However, social, economic and environmental pressures have meant that some communities rely more on food purchased from the stores, which can be unhealthy and expensive, leading to high rates of food insecurity and chronic health problems in many communities in the North. Northern communities are now dealing with the impacts of climate change that are increasing pressure on the food system by limiting both access to the land and the availability of traditional food sources. This research presents a case study from the Northern Canadian boreal community of Kakisa, Northwest Territories. Using a Participatory Action Research (PAR) methodology, community members play an active role in identifying threats to the community food system, as well as developing community-based solutions to foster adaptation and transformation of their food systems to become more resilient to the impacts of climate change. By using the Community Capitals Framework to identify multiple stressors on the food system this research illustrates how a community can allocate available capitals to adapt to the impacts of climate change as well as identify which capitals are required to build a more sustainable food system.
\end{abstract}

Keywords: Food security; climate change; adaptation; participatory action research; resilience; Northern Indigenous communities 


\section{Introduction}

Throughout Canada's North ${ }^{1}$, Indigenous people and ecosystems are linked together. This close relationship with the land and an understanding of natural variability inherent in the ecosystem has enabled communities to thrive. The land is a source of cultural and spiritual well-being, and is also the foundation for community food systems, which continue to be based on subsistence harvesting - hunting, fishing and gathering - and function through social and cultural customs and traditions, such as food sharing (Abele, 2009; Chabot, 2003; Collings, 2011; Collings, Wenzel, \& Condon, 1998; Condon, Collings, \& Wenzel, 1995; Dombrowski, Khan, Channell, Moses, Mclean, \& Misshula, 2013; Skinner, Hanning, Desjardins, \& Tsuji, 2013).

Community food systems have needed to adapt and change over time, mostly to seasonal changes on the land, migration and availability of animals, and other local variables (Berkes \& Jolly, 2001; Kofinas et al., 2010). Traditional knowledge, a place-based system of knowledge based on practice, experience and belief regarding the close relationship between humans and the environment, functions as a form of adaptive management that has allowed communities to continually adapt and thrive in this sometimes harsh environment (Armitage, Berkes, Dale, Kocho-Schellenberg, \& Patton, 2011; Berkes, 1999; Berkes, Colding, \& Folke, 2000; Parlee, Manseau, \& Lutsel K’é Dene First Nation, 2005).

The relationship between communities and the land has been changing, however, and with it the food system people rely upon. Numerous broader issues such as social, economic, and, political factors, have, and continue to, shape communities and food systems in the North (Ford, Smit, \& Wandel, 2006; Furgal \& Seguin, 2006; Loring \& Gerlach, 2009. These issues include colonialism and the transition into settlements driven by government policies, the introduction of the wage-based economy, and land and resource rights (Power, 2008). Global change, which encompasses both environmental and societal changes, has deeply impacted Indigenous communities, and as a result, individuals depend less on the land for their livelihoods and more on the market economy to meet their needs (Loring \& Gerlach, 2009). The need for income is now crucial due to the high cost of living in the North, but employment leaves less time to participate in traditional activities. With less time spent on the land accessing the traditional economy and harvesting traditional food, communities become more dependent on store-bought foods and other goods and services.

As a consequence, past decades have seen a transition in the diets of Indigenous communities in the Northwest Territories (NWT), and across the globe, moving away from traditional food sources to food purchased from stores (Council of Canadian Academies, 2014; Kuhnlein \& Receveur, 1996; Kuhnlein, Receveur, Soueida, \& Egeland, 2004; Kuhnlein \& Receveur, 2007; Popkin, 2002). This change is having a negative impact on the health of these

\footnotetext{
${ }^{1}$ We define Canada's North as comprising of the three Northern Territories of Yukon, Northwest Territories, Nunavut as well as Nunavik (northern Quebec) and Nunatsiavut (in Labrador). However, cited studies from the literature also include Indigenous communities from Northern Ontario, and Alaska.
} 
communities as purchased food often provides less nutritional value, more energy in the form of carbohydrates and fat than traditional diets, and has been linked to increases in diet-related disease such as obesity and diabetes(Egeland, Johnson-Down, Cao, Sheikh, \& Weiler, 2011; Gagne et al., 2012; Johnson-Down \& Egeland, 2010; Kuhnlein et al., 2004; Kuhnlein \& Receveur, 2007; Receveur, Boulay, \& Kuhnlein, 1997).

However, as the high cost of food and lack of affordable, nutritious options are major barriers to food security in the North, the high cost of supplies and equipment needed for harvesting food from the land are also important factors to consider (Council of Canadian Academies, 2014). Also of concern is the fact that some youth are not participating in traditional practices, offering fewer opportunities for transfer of knowledge from Elders. As a result, youth often lack the skills needed to survive on the land and bring back food for the community, which puts additional stress on the community's ability to access and share food from the land (Power, 2008; Pearce et al., 2009a; Beaumier \& Ford, 2010). As a result, food systems that have emerged are complex, involve multiple factors and stressors, and reflect the rapid social, cultural, and political changes that communities have undergone over the last several decades. These food systems are poorly understood and the barriers that communities face in meeting their nutritional needs has led to alarming levels of food insecurity measured at 24 - 69 percent across the North (Council of Canadian Academies, 2014, Rosol, Huet, Wood, Lennie, Osborne \& Egeland, 2011; Tarasuk, Mitchell \& Dachner, 2016)).

To compound the barriers that northern Indigenous communities face in achieving food security, the impacts of climate change are rapidly affecting ecosystem form and function in the region. Permafrost thaw, increases in food web contamination, changing migratory patterns of animals, increases in intensity and frequency of wildfire, and changes in hydrology all impact access and availability of traditional foods (Andrachuk \& Smit, 2012; Chen et al., 2013; Ford et al., 2008; Ford, Pearce, Duerden, Furgal, \& Smit, 2010; Ford, Smit, \& Wandel, 2006; Guyot, Dickson, Paci, Furgal, \& Chan, 2006; IPCC, 2014; Nickels, Furgal, Buell, \& Moquin, 2006; Pearce, Smit, Duerden, Ford, Goose, \& Kataoyak, 2009b; Pearce, Ford, Willox, \& Smit, 2015; Wakegijig, Osborne, Statham, \& Issaluk, 2013), with many of these issues projected to intensify in the future (Price et al. 2013, IPCC 2014). But the impacts of climate change go further than disruptions to the ecosystem goods and services, threatening other services and infrastructure communities depend on (Prowse, Furgal, Chouinard, Melling, Milburn, \& Smith, 2009). Therefore, the food systems that are currently straining to provide access to adequate and affordable food are also vulnerable to the impacts of climate change and constitute an important challenge for communities in the North.

The focus of this paper is twofold: 1) to use a novel approach to describe a food system in a northern Indigenous community that will better reflect the unique socio-economic and political landscape experienced as well as the impacts and pressures of a changing climate. 2) to offer a case study in participatory research that serves to empower community members to make positive changes to their food system in the face of climate change. To describe the food system a northern Canadian Indigenous community, this study utilizes the Community Capital 
Framework (CCF), developed by Flora et al. (2004) and built upon rural sustainability and livelihoods work by Scoones (1998). Sustainable Livelihoods examines the capitals and assets people need to make a living, and these livelihoods are sustainable when they are resilient to outside stresses (Scoones, 2009). Under a livelihoods approach, climate change is a stressor, but one of many that can impact several systems. The capacity for people to adapt to this stressor relies on their ability to access different capitals, which are also impacted by the same systems (Connolly-Boutin \& Smit, 2016). Sustainable Livelihoods approaches are emerging as a focus of climate change adaptation literature and food security studies (Connolly-Boutin \& Smit, 2016; Levine et al., 2004; Nkem, Somorin, \& Sonwa, 2013; Penn, Gerlach, \& Loring, 2016) as they acknowledge the needs of the people involved, and not just the issues and solutions (Levine et al., 2004).

The CCF differs slightly from other Livelihoods approaches in that it is based on seven dimensions of capital contained within a community: natural, social, cultural, political, built, financial, and human (Table 1). Each of these capitals can be viewed as individual systems that interact with one another and can be used to create capitals or resources that contribute to healthy, vibrant communities, economies and ecosystems (Flora, Flora \& Fey, 2004; Emery \& Flora, 2006). This approach is comparable to other emerging definition of food systems, including complex adaptive systems (Stroink \& Nelson, 2013) and systems of systems (BlayPalmer, Sonnino, \& Custot, 2015; Hipel, Fang, \& Heng, 2010), and are defined by place and local circumstances (Marsden, 2012). By using the CCF, however, these complex systems are named in terms of the seven different capitals, providing us with a starting point for analysis of food systems and discussion.

CCF has been utilized in community development, resilience, and planning (Emery \& Flora, 2006; Ashwill, Flora and Flora, 2011; Stone \& Nyaupane, 2015) but this case is used to represent the factors that influence the food system. Adaptations are most successful at reducing vulnerability at the community scale (Ford \& Smit, 2004), which means sharing these examples and case studies can provide lessons to other communities in bottom-up approaches to decision making and implementation (Smit \& Wandel, 2006). Adapting local food systems to become more resilient in the face of climate change is therefore key to the long-term future of communities in the North.

\section{Community description}

The community of Kakisa, located in the South Slave region of NWT, is home to the Ka'a'gee Tu First Nation (KTFN). This small Dene community of approximately 50 people is accessible year-round by the Mackenzie Highway and is located between two larger administrative centres, Hay River (120 km) and Fort Simpson (320 km). Kakisa is approximately $370 \mathrm{~km}$ to Yellowknife, the capital of the territory (Figure 1). The KTFN's traditional territory occupies 
approximately 10,000 square kilometers within the Taiga Plains ecozone which is comprised of patches of boreal forest intermixed with peat plateaus and wetlands.

Table 1: Description of Community Capitals (Source: Flora et al., 2004)

\begin{tabular}{|c|c|}
\hline Capital & Description \\
\hline Social & $\begin{array}{l}\text { Connections and networks among people and organizations or the social glue to make } \\
\text { things happen. }\end{array}$ \\
\hline Cultural & $\begin{array}{l}\text { Reflects the way people "know the world" and how to act within it. Cultural capital } \\
\text { includes the dynamics of who we know and feel comfortable with, what heritages are } \\
\text { valued, collaboration across races, ethnicities, and generations. Cultural capital } \\
\text { influences what voices are heard and listened to, which voices have influence in what } \\
\text { areas, and how creativity, innovation, and influence emerge and are nurtured. }\end{array}$ \\
\hline Natural & $\begin{array}{l}\text { Those naturally occurring physical assets in a location, including resources (e.g. } \\
\text { minerals, forests, waterways), amenities and natural beauty. }\end{array}$ \\
\hline Financial & $\begin{array}{l}\text { Access to financial resources to support community capacity building, social and civic } \\
\text { entrepreneurship. }\end{array}$ \\
\hline Political & $\begin{array}{l}\text { Access to power, organizations, connection to resources and power brokers. Ability of } \\
\text { people to find their own voices and contribute to community well-being. }\end{array}$ \\
\hline Human & $\begin{array}{l}\text { Skills and abilities of people, including access to outside resources and bodies of } \\
\text { knowledge to increase understanding and to identify promising practices. Human } \\
\text { capital also addresses the capacity to "lead across differences," to focus on assets, to be } \\
\text { inclusive and participatory, and to be proactive in shaping the future of the community } \\
\text { or group. }\end{array}$ \\
\hline Built & $\begin{array}{l}\text { The physical infrastructure that supports the other community capitals (roads, } \\
\text { buildings, services etc.). }\end{array}$ \\
\hline
\end{tabular}

The area also includes two large lakes, Kakisa and Tathlina, which are connected by a series of rivers to the Mackenzie River. The community uses the area for a wide variety of harvesting purposes, including hunting, fishing, gathering and trapping. As such, the community maintains strong traditions and ties to the land and most residents rely on traditional foods as a crucial component of their diets with 94.4 percent of the community having obtained most or all (>50 percent) of their meat through hunting or fishing (Northwest Territories Bureau of Statistics, 2013). The community's most important food source is moose, but other large animals, such as woodland caribou, are harvested as opportunities arise. The lands around Kakisa are also a migratory stop for many species of waterfowl, which are typically hunted in the spring. Fish, is also an important food source for the community, both for personal use and through a small commercial fishery that generates income for several community members.

As the smallest community in the territory, Kakisa has limited access to infrastructure and services and therefore must depend on resources in nearby communities, increasing costs and time commitments due to travel. Even though Kakisa has year-round road access, adequate alternatives to traditional foods are not always immediately available or are not easily accessible; 
the closest store is $120 \mathrm{~km}$ away and food options there are limited and expensive. No infrastructure for drinking water or wastewater exists in the community, so services from Hay River are required at a cost to the community. The small size of the community also limits economic opportunities for community members.

Figure 1: Location of Kakisa, NT (Other communities and roads shown)

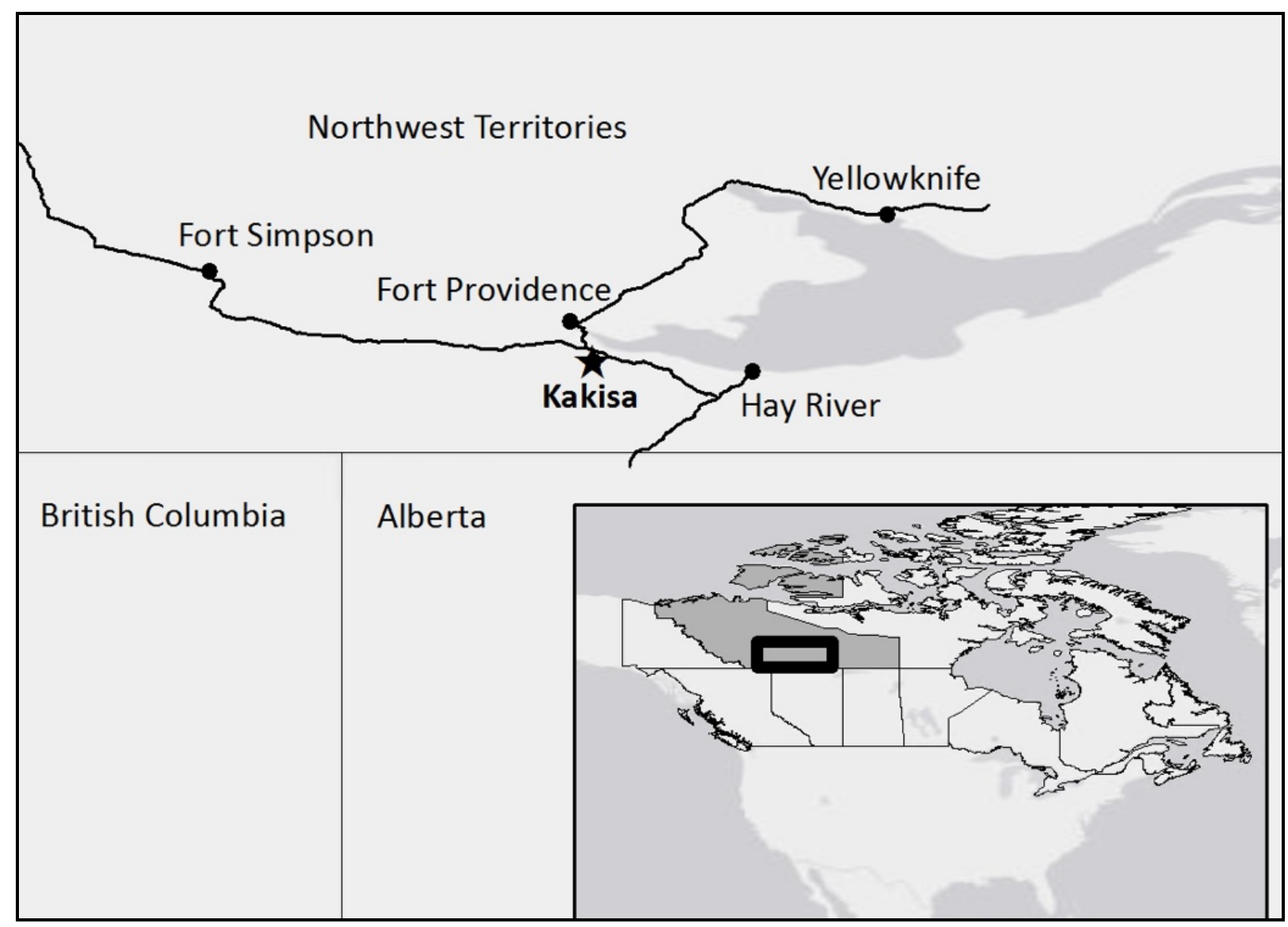

Employment through the Band office (the official community administration), local construction jobs, or through the commercial fishery provides income for some, while others find employment outside of the community. The closest nurse's station is in Ft. Providence, roughly a one-hour drive away. The community has a small school (K-12), and the Band office and new community hall hosts community gatherings. Development pressures are also an issue for the community, with oil and gas extraction occurring in the Cameron Hills area (located to the south of Tathlina Lake) and proposed forest management and wood pellet production in other areas of their traditional lands. The community is concerned about the impacts of these developments, and others, on the health of the land. As there is currently no land claim settlement in place in the region, the community has limited ways it can have a say in, and protect, their land. One option that the KTFN has been pursuing for years is obtaining protected areas status for their traditional lands. A completed protected area agreement would ensure the land is managed to conserve 
biodiversity and ecosystems, establish a land management authority, and protect traditional land uses (NWT Protectes Area Strategy Advisory Committee, 1999).

\section{Methods}

One of the most important features of this research is how it was driven by the community. The community of Kakisa, through the Band Council and the community's Environmental Coordinator, reached out to researchers through a mutual connection (Ecology North, an environmental non-governmental organization (NGO)) in the NWT, to have this work done as the community was concerned about the impact that climate change was having on their ability to harvest traditional foods from the land. Working through Ecology North, which has developed social capital in communities throughout the NWT, a successful grant application was developed with the aims of addressing the issues of food security and climate change as proposed by the community.

All organizations involved (community, NGO, and academic institution) formed the research team and were able to contribute their expertise to the project, guided by the interests of the community. From the beginning the community directly influenced project goals, methods, and deliverables as an active partner. The goal of the research was to create a food security action plan for the community that featured concrete steps and projects to ensure food security for future generations.

The basis of this research approach borrows from other studies that have conducted vulnerability and health studies in northern communities (Ford \& Smit, 2004; Parlee et al., 2007). This Participatory Action Research (PAR) approach ensures the research is communitydriven and that it responds both to the practical concerns of the community and furthers the goals of social science through the active collaboration of researcher and participant in co-learning (Gilmore et al., 1986).

With origins in community empowerment, social action, and community health and development (Altrichter, Kemmis, McTaggart, \& Zuber-Skerritt, 2002; McTaggart, Wallerstien \& Bernstein, 1994), PAR strives to achieve community-driven/defined social change and transformation (McTaggart, 1999). PAR methodologies have been used in building food systems across Canada (Blay-Palmer et al., 2013), including Indigenous communities (Skinner et al., 2013; Stroink \& Nelson, 2013). Consistent with other work in the North, which utilizes Community Based Research (CBR) approaches (Berkes \& Jolly, 2001; Pearce et al., 2009a; McGregor, Bayha, \& Simmons, 2010; Armitage et al., 2011; Tondu et al., 2014), research was conducted alongside representatives of the community, observing - but also contributing to their activities. Through building trust and open and transparent communications these partnerships and collaborations directly benefit the community (Angell \& Parkins, 2010; Tondu et al., 2014). 
The PAR methodology used here involves fostering as much opportunity for community engagement and participation as possible (Minkler \& Wallerstein, 2011). The use of community events where food was provided alongside displays of maps, historical aerial photos, and graphs showing environmental changes over time (such as temperature, precipitation etc.) fostered such participation (Wolfe et al., 2011). An introductory workshop was held in August 2014 at the Band office in the community. Events like this allow researchers to engage in informal conversations about the content of the visual material with community members and listen to the stories and concerns of individuals. The interactions allowed researchers to gain insights into community priorities and were an opportunity for researchers to interact with community members and begin to build familiarity and trust. This initial event helped to establish research questions at the intersection of climate change and access to traditional food that are important to communities.

During a one-week period in November of 2014, researchers returned to the community for more meetings and to conduct interviews. A community meeting was held with prospective participants to familiarize them with the research objectives, methods, and to answer any questions regarding the project. As this was the first time participating in an interview for many community members, the researchers ensured that they were made aware of the process of informed consent, and the research was made flexible to accommodate their needs and preferences. This included the timing and location of the interviews. In all, 21 community members were interviewed, encompassing almost half of the community. Such high engagement was made possible by the community's Environmental Coordinator, who spent time talking to and recruiting community members.

Participants who were able to speak to changes on the land, including Elders, harvesters, and others, were selectively sampled with the help of community partners and invited to participate. Each interview took approximately one hour and was conducted in the language of their preference (South Slavey or English). For all interviews conducted in Slavey, an interpreter was used to consecutively translate questions and answers. Interviews were mostly conducted in the Band Council offices, but some were conducted in the homes of some residents if this was their preference. Interviews were semi-structured around open-ended questions so there was enough flexibility to explore more detail based on specific experiences and expertise of each participant (Hay, 2000).

Questions asked during interviews ranged from a community definition of health, links between health and traditional foods, to how changes on the land are impacting health and access to traditional food. Most importantly, participants were asked what community-based solutions they would like to see to address some of the vulnerabilities identified during these conversations. Questions were modified to suit the participant. For example, Elders were asked to tell stories about their experiences on the land from the past, whereas current land users were asked questions more relevant to present experiences and recent environmental changes (for example, what they see in their landscape and how it has changed over the past few years). All interviews were digitally recorded and participants were reimbursed for their time. 
Audio recordings were transcribed verbatim and researchers read through all of the data files to gain a full understanding of the contents of the interviews. A general discussion amongst the research team followed to help identify themes and coding structure (Mays \& Pope, 1995; Bradley, Curry \& Devers 2007). Resulting data was organized according to themes and assembled in a results document, which was shared and discussed with a community representative. Data verification was done by giving community members the opportunity to review transcripts and approve quotations before any information was made public. Respondents had the opportunity to either remain anonymous or associate their name with their quotations. A results workshop was conducted in February 2015 to report the preliminary findings of the study back to the community. This workshop allowed individuals to comment on the findings prior to the finalization of reports but also for a discussion on "Next Steps" to determine what actions the community wants to take to address some of the findings. Essentially, the community was describing initiatives they wanted to undertake to build a more resilient food system. This discussion allowed for the formation of a work plan for the community and set priorities for future work. This was a part of the iterative process that builds PAR as well as trust. Final results were shared with community members through plain language documents and disseminated by the community's Environmental Coordinator. This research approach and methodology was approved by the Research Ethics Board of Wilfrid Laurier University and through the Aurora Research Institute, the research licensing organization for the NWT.

One of the innovative elements of the methodology used here is the partnership and personal relationships built with the community's Environmental Coordinator. This individual has been involved in environmental monitoring projects through government departments and non-governmental organizations, and has coordinated field sampling for fish, water and wildlife monitoring with government and university researchers from WLU. As such, the Environmental Coordinator has a high capacity to conduct research and was adept at providing logistical support for this project, both of which were key to its success. Of most benefit to the project was the social capital and connections this person has in the small community which allowed for easy communication and connections to community members and local decision makers (Chief and Band Council). Their affinity for social networking and text messaging led to increased and timely communication and interaction in the community, which allowed the project to proceed at a more rapid pace, especially when dealing with last minute logistical challenges and accommodating community needs. What emerged as a powerful driver behind the research and subsequent follow up projects was their personal drive to conduct work that made a positive impact in the community. This drive not only enabled them to champion the research, but pushed much of the research from participatory and collaborative to Action Research.

This relationship helped to foster research links outside of the community. For example, the Environmental Coordinator attended meetings at the university in Waterloo, Ontario, with research partners from around the globe, and was able to help shape further grant applications and collaborations. The positionality of the Environmental Coordinator made a significant contribution to the overall project and speaks to the importance of building capacity and 
empowering communities, and the role of local leaders to be active members of the research team and to enhance participation of community members. Another key element was the partnership between an academic institution, the community, a territorial non-governmental organization, and government agencies to conduct this research. Part of building resilience and fostering food system development is to build social capital by fostering connections and networks within (bonding social capital) as well as outside of (bridging social capital) the community (Blay-Palmer et al., 2015). By building a strong network of organizations, where each partner brought their own expertise to the research team, the group was able to leverage other networks and funding, and bring diverse experience in similar or related work to the community (Putnam, 1995; Emery \& Flora, 2006). This became important after the initial research was conducted and community-defined projects were prioritized. As funding sources were identified, different partners that were more suited for specific grants were put forward as the proponent with the other groups offering letters of support and assistance in writing. The community had final approval on all grants moving forward. This partnership leveraged the capacity of other groups to target and obtain funding sources for the community in a way that benefited all groups involved.

\section{Results and discussion}

The members of the Ka'a'gee Tu First Nation have observed changes to the land, animals and water around them that they attribute to the impacts of climate change and are concerned that these changes are impacting food security in the community. Interviews with community members revealed that the importance of the land, social connections, and culture are the basis of the community's food system and their connection to place. However, issues, concerns, and barriers to food security due to the impacts of climate change and other societal factors were identified. Participants also shared ways that they are currently adapting to the changes on the land, but more importantly, shared ideas for how the community can strengthen their food system to be more resilient to the impacts of climate change. This section is therefore organized into three subsections: describing the community food system, impacts of climate change, and building capitals for a more sustainable food system.

\section{Describing the community food system}

Through preliminary project scoping and engagement events it was apparent that the preferred food system for the community relied on traditional food. What emerged during interviews and discussions was a more detailed understanding of the importance of the land and traditional foods to the community's health and well-being. Community members spoke about the importance of being on the land and eating traditional foods as the foundation of being healthy. 
The link between a healthy ecosystem, clean water, and a healthy community emerged, as one informant explained,

So I guess the health depends on the animals. My grandfather used to talk about things like that. He said we have always been rich in animals and their fur and moose and stuff like that. And our health depends on the health of the animals, the fish and that kind of stuff. -Lloyd Chicot

Therefore, in terms of community health and well-being, as well as the community's food system, the land, water, and traditional foods, which are important components of natural capital, play crucial roles. Another important component of the food system is the ability to access natural capital through cultural capital, which relies on learning skills and traditional knowledge that is passed through generations. Food sharing, a common practice in Indigenous communities, and part of the social economy, ensures that all community members have access to traditional foods, particularly those in need (McMillan \& Parlee, 2013). Overall, being on the land and eating traditional foods and practicing traditional activities, including the sharing of food, is important to community members in Kakisa and was seen as a main strength of the community.

The traditional values of our people. We still follow the traditional lifestyle. People are very...good and polite, and we help one another. Helping one another in the community. We share with each other. So you could say that it is like one big family. -Margaret Leishman

As such, natural, cultural and social capitals form the basis of the food system in Kakisa. However, like other communities in the North, the food system has changed over recent years. Accessing natural capital by hunting, fishing and gathering now requires more financial capital as money is needed to purchase gas, gear, and supplies. To build this financial capital, community members need access to jobs, something not readily available in this small community, so they need to travel to other communities for work. However, community members spoke about how working leads to less time available for on-the-land activities and they therefore rely on sharing networks and/or store-bought food more often. Store bought food was also discussed as being a necessary part of the food system, but was perceived by many to be unhealthy compared to traditional foods and more expensive, as has been observed in other studies (Lambden, Receveur \& Kuhnlein, 2007; Wesche \& Chan, 2010).

Being able to eat traditional food I think is a good way of being in good health. You go to the store and buy hamburger and eat hamburger and eat processed chicken and stuff like that. You are putting garbage in your body when you can just go out on the land and go get it.

-Anonymous community member 
With the nearest grocery store located roughly an hour away, the time and financial capital needed to travel to the store, let alone the cost of food, was a concern. For many, the transition away from traditional food has resulted in greater food insecurity, particularly amongst those who are not able to harvest foods nor have family members able to share enough with them.

Compared to way back, we had plenty food and today it's not [like that]. Today we purchase our food and it's very expensive.

\section{-Community Elder}

Some harvesters, particularly those with young families, find it difficult to find the balance between the need to work in the money economy and being on the land. One participant shared their experience:

Actually it really is [hard to find a balance], especially when I am working now. But I would like to go back on the land, but there is not much income, especially with trapping. I used to do quite a bit of that. But there is just not much in it. It is a lot of work, and everything costs money now.

\section{-George Simba}

Although maintaining on-the-land traditions and being a close-knit community were mentioned as strengths of the community, there is a general concern that those strengths may be at risk in the future. Many community members were concerned that youth, in particular, are not as interested in traditional foods and activities, and more importantly, do not speak Slavey. Youth, as well as many of the younger community members speak only English and Elders mainly Slavey; therefore, language is seen as a major barrier preventing interactions between youth and Elders. This could impact the long-term access to cultural capital if traditional knowledge and skills are not passed down to the youth who will be providing food for the community in the future.

Although the community has held many on-the-land camps for youth and community members in the past and wishes to continue to do so, it was noted that while there are opportunities to do more on-the-land activities and community hunts, there are issues with low participation due to time commitments such as work, or low interest. Low participation in an already small population is a challenge. As the community is active in meetings and discussion to protect their lands and contribute to regional initiatives it is taxing on the few individuals that represent the Band and their interests. This small community is being asked to contribute to many initiatives and discussions that will shape the future of the lands and their food system.

Using information from the interviews as well as through preliminary project scoping and discussion with community members, an outline of the community food system in terms of community capitals was created (Table 2). Each key point determined through the research had either a positive or negative influence on each capital. For example, being a small, close knit community where food sharing is common practice indicates the presence of strong bonding social capital, and connections between community members that is an asset to the food system. 
However, issues of low participation and engagement as well as having some community members leaving in pursuit of jobs or training can decrease social capital. Cultural capital is maintained through practicing traditional ways of life and passing that knowledge down to the youth, and although the community prides itself on living the traditional way of life, barriers such as loss of language, participation, and time commitments threaten that capital. The current food system, which the community depends on for health and well-being, is being strained from the depletion of too many capitals at once. Now, and maybe most importantly, the pressures of climate change on community natural capital, as detailed below, will add more pressure on the food system.

Table 2: Summary of community capital in the food system of Kakisa as determined though community interviews, showing key elements that contribute to $(+)$ or degrade (-) capitals

\begin{tabular}{|c|c|}
\hline Capital & Attribute \\
\hline Social & $\begin{array}{l}\text { (+) Strong social economy (food sharing) } \\
\text { (+) Small, close-knit community (bonding social capital) } \\
\text { (+) Experience with research networks outside of community (bridging social capital) } \\
\text { (-) Some issues with degradation of bonding social capital in the community. } \\
\text { (-) People leave community for education and jobs }\end{array}$ \\
\hline Cultural & $\begin{array}{l}\text { (+) Most community members maintain traditional practices and activities and a strong } \\
\text { connection to the land } \\
\text { (-) Limited time available to take part in traditional activities (for some) } \\
\text { (-) Language as barrier to transfer of traditional knowledge } \\
\text { (-) Some youth not as engaged in traditional foods and activities }\end{array}$ \\
\hline Natural & $\begin{array}{l}\text { (+) Abundant sources of traditional food } \\
(+) \text { Abundant access to clean water } \\
(-) \text { Concerns of impacts of development on the health of the land }\end{array}$ \\
\hline Financial & $\begin{array}{l}\text { (+) Access to community funding and government grants } \\
\text { (+) Small commercial fishery } \\
\text { (-) Limited availability of jobs in community } \\
(-) \text { High cost of living (food, gas, and supplies) }\end{array}$ \\
\hline Political & $\begin{array}{l}\text { (+) Active local government } \\
(+) \text { Pending protected area designation } \\
(-) \text { Limited decision making ability in terms of control of lands }\end{array}$ \\
\hline Human & $\begin{array}{l}\text { (+) Engaged community (active in training opportunities) } \\
\text { (-) Small population } \\
\text { (-) Time and effort needed to travel to other communities for store-bought goods. }\end{array}$ \\
\hline Built & $\begin{array}{l}\text { (+) All-weather road access } \\
(+) \text { Local school } \\
(+) \text { Community hall and culture camp } \\
\text { (-) Limited infrastructure (health, water, etc.) } \\
\text { (-) No store }\end{array}$ \\
\hline
\end{tabular}




\section{Impacts of climate change on the food system}

Climate change is having an impact on the lands, waters, and animals around Kakisa. Through interviews and engagement, community members shared stories and experiences about the changes witnessed on the land and provided context as to how the broader global changes have impacted their community and their food system. These changes have caused them to become worried about the health of the land, water, and animals that they depend on as part of their culture and also for food. In general, the community has noticed a warmer trend in recent years, not only in the summer months, but also in the winter. Elders recounted stories of times in the past where the cold temperatures would crack trees, but it had not been that cold for quite some time. These changes in temperature are having impacts on the community's ability to harvest traditional foods. More variability in weather is making it harder to predict conditions and requires people to wait longer for lakes and routes to freeze and adjust to earlier melt in the spring. Storing and preparing food while on the land is more problematic as well, bringing up issues of food safety. As one participant described it,

The weather is really warm most years, like September when we went goose hunting. We had some moose meat hanging out drying and smoking, and those spoiled because the weather was really warm at the end of September and usually it is cold enough so we just let the meat hang.

-George Simba

Changes on the landscape due to permafrost thaw results in land subsidence, conversion of forest to muskeg, and changes in water resources, and have significantly affected the lands around the region (Baltzer, Veness, Chasmer, Sniderhan \& Quinton, 2014; Coleman et al., 2015; Quinton, Hayashi \& Chasmer, 2011; Williams, Quinton \& Baltzer, 2013). This landscape change, and more importantly changes in water and ice conditions makes travel more difficult and less safe. Although changes in landscape have been witnessed by community members, their concerns were more focused on changes in water. Waterways are an important method of accessing the land, vital to ecosystem health and is a central part of the definition of place (Fresque-Baxter, 2013).

These changes are experienced more in the winter months when the land is more accessible and where observations and concerns are based around what does or does not freeze as it used to. For example, there is an increase in the risk of skidoos becoming stuck in unfrozen muskeg or falling through the ice because of changing conditions. With these changes, the need to be more cautious on the land was identified in the interviews and more broadly in the literature (Ford et al., 2008; Pearce, Ford, Caron \& Kudlak, 2012). This requires harvesters to know what to watch out for and take time to check conditions, such as ice thickness and patches of "candle” ice, described as when ice looks like swiss cheese, so that it may be dangerous to cross. 
Lack of rain, and how dry the past few years have been was also a common theme during discussions. The impacts of the dry conditions on food sources, such as berries as well as the overall health of the lakes and waterways were mentioned as major concerns.

There's no berries. The weather in the summer is too hot and the berries dry up fast.

\section{-Community Member}

Lower water levels and an increase in water temperature in both lakes have been observed, particularly in the past few years. Water levels have been so low in Tathlina Lake that the 2014 fall moose hunt was called off because the plane was unable to land in the shallow waters. Not being able to conduct this hunt worried several community members for many reasons. It is an opportunity for many community members to be on the land together, fostering social capital, and intergenerational knowledge transfer, and to build cultural capital. It is also an opportunity to fill people's freezers with meat for the winter. The fall hunt is an important activity to support food security for the entire community as moose meat is brought back and shared. In addition, low lake levels, particularly in the shallow Tathlina Lake, caused some community members to be concerned about the long-term health of the fish population.

We are worried about the lake, especially the lake to the south, Tathlina. There it is pretty shallow. It is probably three feet or four feet. If it gets any shallower, I am not sure about the fish. I worry about that more than I do with this lake (Kakisa) because this lake is deeper. If the water drops, there will still be enough for the fish. It is the other lake that I worry about. Everyone depends on that lake for fishing. And in winter time, for commercial fishing too.

-George Simba

Fish are a plentiful source of food, but are an important community staple as they are relied on when other food sources are not available, but also as income through a small commercial fishery. The community has invested in fish processing infrastructure and wishes to see the economic benefits of this investment continue. As such, fish, and therefore the health of the waters in the region, play a vital role in the health of the community's food system, influencing several capitals.

Community members have also noticed changes in animals. New animals have appeared on the land and waters, including pelicans, cougars, and deer, while traditional foods, moose in particular, can be harder to find. The introduction of new species does not necessarily add new food options for the community nor replace another species as has been proposed in other studies ( Andrachuk \& Smit, 2012; Ford \& Smit, 2004; Ford, Smit, Wandel \& MacDonald, 2006b; Ford et al., 2008; Wesche \& Chan, 2010). Here, when speaking of the possibility of harvesting deer to support the community, one Elder and active harvester spoke of reluctance to do so because of the lack experience or traditional knowledge of harvesting and preparation methods. Lack of cultural background about these new species limits their use in the community's food system. 
As for other changes in animal availability, community members are noticing timing of spawning runs and animal migrations are different than they used to be. This results in missing opportunities to harvests species at times and locations as they were used to doing in the past. There is a decline in the health of some animals, with more frequent observations of ticks on moose and parasites in fish. There is concern that the land is changing so rapidly that traditional knowledge can no longer predict or explain what the community sees on the land.

Table 3: Impacts of climate change on community capitals related to traditional food access.

\begin{tabular}{|c|c|}
\hline Capital & Climate Change Impacts \\
\hline Social & (-) Limited ability to be on land as a group (low lake levels cancelling community hunts) \\
\hline Cultural & $\begin{array}{l}\text { (-) Traditional Knowledge not reliable to predict conditions } \\
\text { (-) Limited opportunity to pass on traditional knowledge (low lake levels cancelling } \\
\text { community hunts) } \\
\text { (-) Limited intergenerational transfer of knowledge increasing risk to harvesters }\end{array}$ \\
\hline Natural & $\begin{array}{l}\text { (-) Warmer temperatures impacting food preparation and storage } \\
\text { (-) Variable weather makes it harder to predict conditions } \\
\text { (-) Low water levels impacting lakes (travel, potentially fish populations) } \\
\text { (-) Drought impacting availability of berries } \\
\text { (-) Health of food species being impacted } \\
\text { (+/-) New species present } \\
\text { (-) Changes in animal availability and timing of migration } \\
\text { (-) Changes to land make travel more difficult }\end{array}$ \\
\hline Financial & $\begin{array}{l}\text { (-) More resources needed to travel further in search of food (gas and supplies) } \\
\text { (-) Resources needed to maintain access to land (clear trails) }\end{array}$ \\
\hline Political & (-) Decreased ability to travel and monitor lands \\
\hline Human & $\begin{array}{l}\text { (-) Increased safety risks while traveling on land } \\
\text { (-) More time and effort needed to obtain traditional foods } \\
\text { (-) Stress due to increased uncertainty }\end{array}$ \\
\hline Built & (-) Trails and cabins on the land need more maintenance \\
\hline
\end{tabular}

The impacts that climate change is having on the food system, as described by community members through interviews, are summarized in Table 3 in terms of community capitals. These impacts, with the exception perhaps of the introduction of new species, were perceived as being negative by the community. Although the main impact of climate change is on natural capital, repercussions are felt in the other capitals that make up the food system. For example, changing conditions on the landscape impacts human capital due to more risk to the harvester and time needed to remain safe. Financial capital is reduced because more time, gas, and other supplies are needed to travel further to avoid hazards and through increase risk to harvesting equipment. These changes on the land can also impact both social and cultural capital if community members cannot access the land or harvest the traditional foods that are part of the culture. 
It should also be noted that the impacts of climate change were identified by participants as having negative effects on the land and food system. Therefore, a food system that was already being compromised due to the depletion of many capitals (see Table 2) is further stressed by the impacts of climate change. For example, if climate change creates further challenges or barriers to accessing the land, fewer opportunities for long-term replenishment of cultural capital through community hunting camps will be available.

\section{Building capital for a more resilient food system}

Allocating existing capitals allows communities to cope with or adapt to the impact of climate change on access to and availability of traditional food sources. However, with the threat of climate change and other factors limiting the creation and maintenance of some capitals, there is the need to build a food system that is more resilient to these stressors. Enabling the community to continually adapt over time to future social and ecological changes by building on community strengths, values, and vision was an important part of this research (Berkes \& Ross, 2013; Ross \& Berkes, 2014). Resilience can be more than just maintaining a system as it recovers from a disturbance, it can be seen as creating opportunities for transformation to more desirable endpoints (Davoudi, Brooks \& Mehmood, 2013). As part of the PAR methodology utilized in this research, participants were asked questions about how to address the impacts of climate change on their food system and to improve access to food for the community.

With all the changes impacting the land, ensuring the safety of harvesters was important to many community members. Being safe on the land now requires more allocation of community capitals. The community informally uses the "buddy system", or going out with a group of harvesters, when on the land. This requires using more financial capital (for additional gas and supplies), as well as relying on human and social capitals. However, harvesters also require proper skills and training to be safe and survive on the land, and to be aware of conditions. Accessing cultural capitals, through traditional knowledge is therefore key to developing these skills. Many participants agreed that learning more on-the-land skills is important for younger harvesters to be safe and survive on the land in case of emergencies where they may need to stay longer on the land than planned. However, creating opportunities for that to happen can be limited by financial capital. As one Elder explained:

To be on the land. That means we need money to make it happen so that we can be on the land and have the Elders to teach the kids. It is also creating opportunities for the Elders to fill their roles as teachers. Elders are always the teachers.

\section{-Community Elder}

Another Elder commented that although community hunts are a good way of being on the land together there is, generally, low participation by some of the youth. 
But a lot of small kids they don't like traveling in the Bush. It's too much work for them I think. The ones that like to do something, they're good. I don't think you'll be able to teach them what they don't like.

\section{-Community Elder}

Ultimately, this disconnect between youth and Elders may have been caused through the impacts of residential schools, where those directly impacted were not able to transfer their knowledge on to their children, who in turn, do not pass it to their children.

A prime example is residential school people. It has effected all of our generations. Because of that, if I went into the school and talked to them for half an hour, they wouldn't know what I am talking about. So, parents need to be taught also to re-learn. And for the Elders to be given their roles again and to re-earn their roles again.

\section{-Community Elder}

Bringing the community back together, and building bonding social capital, therefore, appears to be a key element in supporting a more sustainable food system and helping the community adapt to climate change as it is key to knowledge transfer. The community identified strengthening social capital over the long-term as a priority, and the Band Council has actively been trying to address this issue over the past several years. The community has held many onthe-land camps in the past allowing youth to gain skills through experience while strengthening social and cultural ties in the community. Language programming was a priority already identified by the Band Council. The Council continues to pursue and develop language learning as a key to understanding and preserving traditional knowledge and the cultural identity of the community.

Encouraging on-the-land activities has been cited as a key adaptation strategy in other studies (Ford et al., 2006a; Pearce et al., 2012; Cunsolo-Willox, Harper, Ford, Landman, Houle \& Edge, 2012). The community wants to continue to pursue other opportunities to build social capital as well and want to see all future projects and research incorporate on-the-land experiences and foster youth and Elder relationships whenever possible. This also fosters truly engaged PAR as the community continues to define the scope and objectives of future research.

In Kakisa, the health of the land and the health of the community is closely tied together. Community members spoke of the importance of doing what they could to help take care of the land and strongly identified with stewardship and monitoring programs as priorities for the community.

If you take care of the land and the animals, then the land will take care of you.

$$
\text { -Terry Simba }
$$

One common practice amongst harvesters was taking pictures of what they saw on the land. In fact, during interviews, many harvesters took out their smartphones and showed the 
research team pictures from their trips on the land. Others mentioned numerous pictures they had taken of changes they have seen on the land. These photos may include conditions and hazards, animal sightings or other interesting occurrences. Through taking pictures and sharing information from the land the community is already engaged in an informal monitoring of change. Although this information was primarily shared through kin relationships, it was agreed that more information should be shared throughout the community as an opportunity to build social capital. As one Elder explained:

We used to share stories all of the time when the hunters and fisher people go out and the trappers. When they come back they used to all come together. The men especially. And they would share their information. You know, if the fur was good, and what area was plentiful. My dad was really good at that and he used to organize those talks all the time. Today people come back here sometime after hunting, and they go into their house and you don't see them again. We need to learn how to share these again.

\section{-Community Elder}

Information, knowledge, and skills are resources, shared in similar ways to traditional foods in communities, flowing through kin relationships (Harder \& Wenzel, 2012). Active harvesters commented on how they would often share information with family members, but not with the broader community, as used to be the case. The interest in sharing photos and capturing conditions and observations on the land illustrates how investments in financial and built capital (technologies such as cellphone networks, internet, phones and cameras) can help build community capitals and foster innovation and adaptations in the community. Initial discussions with harvesters as well as other community members during the 'Results Workshop' indicated that the community was interested in further developing a monitoring initiative based on the photos and information community members were already collecting.

Community members were interested in learning more about mapping, using GPS, and contributing to an online database accessible by community members. This initiative may help to build political capital as the database of images and observations can be used to enhance decision making, at numerous levels, contribute to ongoing research in the region, and promote stewardship of the land (Bennett \& Lantz, 2014; Gill, Lantz \& Gwich’in Social and Cultural Institute, 2014).

Another initiative that the community felt was important to take care of the land was through waste management. Being clean and free of garbage was cited as a major strength in the community.

As individuals, we need to take care of the land. A big thing with the land is how well you take care of it and how you take care of your garbage. 
Participants identified numerous issues with waste in the community, citing lack of appropriate recycling infrastructure, concern about pollution at the community landfill, desire to keep the community clean, and to do their part to take care of the land. The ties between food availability and waste management also emerged, as the community feels that their landfill is a source of contamination for the land, and therefore animals that they find near the landfill may not be suitable for consumption. So, diverting waste from the local landfill could increase the availability of food. However, waste diversion is challenging in the region as the nearest recycling collection facilities are located in Yellowknife. Although some community members admitted to taking their recycling to Yellowknife when they travel there on business, it is not a sustainable solution. The community is interested in exploring other options, such as working with other communities to create waste management solutions as well as composting organic wastes.

Building a more sustainable community food system by growing food was an adaptation that each community member discussed during interviews. Everyone had positive responses to the idea of either community gardens or individual garden plots, and many interviewees shared positive stories about past gardening experiences in Kakisa. Many community members saw the benefits of gardening to be eating healthier food that they could grow themselves, and would be a less expensive alternative to food from the store. This may also lead to less travel to Hay River for groceries and a lower burden on financial capital allowing for more resources to be allocated to being on the land. Government programs in the NWT are available to pay for the installation of gardens and related infrastructure, making gardens an option for those who are interested. However, community members also identified some key barriers to growing their own food, specifically, a lack of education and recent experience around gardening, and most importantly a lack of time to tend the gardens.

If people could come and make a garden and show us how to do it. We could do it, we could weed and water it and stuff like that. I don't know who to ask. Some of them they make a box and they make a garden in there. That would work. It would be nice to have something to grow your own vegetables. So you wouldn't have to go all the way to Hay River for that stuff.

-Sarah Chicot, Elder

Building human capital and skills around gardening are needed. This will, for the most part, be a completely new resource to add to the community as Dene culture has had little experience with growing food. The literature does contain some evidence of gardening in Indigenous communities in the past in the region (Helm, 2002; Loring \& Gerlach, 2010) and there have been several attempts at gardening in Kakisa in the past, mostly through Band, school or government involvement. These gardens ultimately failed because either the community champion moved away or a garden was built under the assumption that community members had the skills needed to care for and utilize it. 
Lessons from these past failures need to be learned. Building capacity and fostering community engagement are key to supporting communities interested in growing food. Fostering partnerships with local resources such as the Northern Farm Training Institute (NFTI) located in Hay River can provide the training and support key to community success. This challenge is not unique to Kakisa. Human and social capitals are needed for many communities in the NWT to support small-scale garden plots and potentially scale-up existing gardens towards larger scale food production (Douglas, Chan, Wesche, Dickson, Kassi, \& Williams, 2014; GWNT, 2015).

Building a more resilient food system and implementing initiatives proposed by community members will require the creation of new and the enhancement of existing capitals. Some capitals can be developed through initiatives already implemented in the community, such as promoting safety and training of young harvesters through mentorship. Or adding new skills and capacity though training.

A summary of the capitals that are required or could be developed through existing and proposed adaptations and initiatives is presented in Table 4. However, as noted, developing programs to foster each capital takes both time and financial capital. The community wants to foster change through programs that engage and involve the community, particularly youth. As such, some of these initiatives have already begun to be developed through partnerships with the community and other organizations. Gardens, for example, were installed in the summer of 2015, planted in part by the school, and supported by hands-on training for community members by NFTI. It is hoped that community engagement and involvement will help to spiral up capitals, where building one capital leads to the development of others, and this in turn can lead to positive changes in the community (Emery \& Flora, 2006).

Table 4: Community capitals being developed or required to foster resilience in community food system

\begin{tabular}{|l|l|}
\hline Capital & Adaptations \\
\hline Social & $\begin{array}{l}\text { Increase community engagement } \\
\text { Use of “buddy system” and community watch to keep harvesters safe } \\
\text { More frequent community hunts and time together on the land } \\
\text { Increase communications amongst harvesters to report conditions on the land }\end{array}$ \\
\hline Natural & $\begin{array}{l}\text { Language programming } \\
\text { "Buddy system” creates opportunity for mentorship of youth } \\
\text { Promote on-the-land camps and community events when possible }\end{array}$ \\
\hline Financial & $\begin{array}{l}\text { Recycling to increase stewardship } \\
\text { Ponitoring land for impacts of climate change and development } \\
\text { Contribute to local and regional land protection initiatives }\end{array}$ \\
\hline Political & $\begin{array}{l}\text { Resources needed to fund community-defined programs } \\
\text { Participate in regional discussion for land protection }\end{array}$ \\
\hline Human & Skills and training needed for initiatives (gardening, mapping, etc.) \\
\hline Built & Infrastructure and tools required programs and initiatives (gardens, etc.) \\
\hline
\end{tabular}




\section{Conclusion}

Climate change is having an adverse impact on the already strained community food systems in the North. These impacts are affecting natural capital through changes witnessed in the land, water, and animals that form the basis of the food system and affect health and well-being in communities. Through the lens of the CCF, this research highlights the interconnections of community capitals and how impacts to natural capital are having broader effects within the community. This research detailed a PAR approach to climate change adaptation where community members were able to determine their own goals and priorities, and work with project partners to identify plans and next steps to help build more resilient food systems. By identifying transformative projects that are important to enhancing food availability, the community is actively defining their food system.

These projects involve key themes of reconnecting to the land, taking care of the land, and growing food, but require the addition of human, financial, and social capitals to enhance capacity, skills, and engagement within the community. Initiatives such as these will take time to implement, which requires a long-term partnership between the community and researcher to build capitals and capacity, reflective of the PAR process. All of the potential programs determined by community members rely on building or maintaining certain capitals. Human capital is required in the form of education, training, and capacity building within the community to learn new skills to implement these programs. Financial capital is needed for these projects and, in some cases, is (or can be) available, but accessing that capital can be difficult if necessary human capital is limited. (e.g. grant writing). The community also strives to have more political capital, as well as to have more say and protection of their lands and natural capitals, which aare the basis of their food system.

However, political capital is limited by human capital as only a few community members are available to represent the community at meetings. But by using the political capital available, and by building social capital through networks that extend outside of the community (through research and monitoring networks or similar initiatives), the community is playing an active role in trying to protect their natural capital. Social capital, either bonding social capital such as community engagement to strengthen ties within the community, or bridging social capital to create networks outside of the community to bring in new knowledge and skills, will be key elements of successful implementation.

The CCF offers a valuable lens for the issues of climate change and food security that are impacting Indigenous communities in the NWT. The capitals approach better describes the complexities of the food system that is both the product of tradition, culture, and the close relationship to the land as well as unique socioeconomic and political pressures that continue to shape communities. The CCF puts the community first and offers a place-based analysis for food system issues. It allows us to see past issues of food and include other issues that impact the community's well-being. It also offers a starting point to better integrate the unique food systems of the North into the broader context of food system literature. This can further act as a bridge to 
bring in new knowledge where communities in the North can learn a great deal from food system studies from around the world. It may be, however, that Kakisa does not be fully represent what is being experienced in other communities in the NWT or elsewhere.

Due to its small size the community has high amounts of social capital, mainly through kin relationships. Larger communities may have a more complex social structure as well as other place-based circumstances that make their food system different. Further work in larger communities would offer a valuable addition to the emerging dialog of food systems in the North. However, communities like Kakisa can also offer lessons for communities around the globe, particularly those communities adapting their own food systems in the face of climate change.

Acknowledgements: The authors would like to express their sincerest appreciation to the members of the Ka'a'gee Tu First Nation, in particular Melaine Simba, for their guidance and contribution to this research. This research was made possible through a grant from Health Canada's Climate Change Health Adaptation Program for Northern First Nations and Inuit Communities. Further support was provided through a Social Science and Humanities Research Council (SSHRC) Partnership grant, Royal Canadian Geographical Society Graduate Research Scholarship, and Polar Knowledge Canada’s Northern Scientific Training Program.

\section{References}

Abele, F. (2009). The state and the Northern social economy: research prospects. The Northern Review 30, 37-56.

Altrichter, H., Kemmis, S., McTaggart, R., \& Zuber-Skerritt, O. (2002). The concept of action research. The Learning Organization, 9(3), 125-131.

Andrachuk, M., \& Smit, B. (2012). Community-based vulnerability assessment of Tuktoyaktuk, NWT, Canada to environmental and socio-economic changes. Regional Environmental Change, 12, 867-885.

Angell, A.C., \& Parkins, J.R. (2010). Resource development and aboriginal culture in the Canadian north. Polar Record, 47(1), 67-79.

Armitage, D., Berkes, F., Dale, A., Kocho-schellenberg, E., \& Patton, E. (2011). Comanagement and the co-production of knowledge : Learning to adapt in Canada's Arctic. Global Environmental Change, 21(3), 995-1004.

Ashwill, M., Flora, J.L., \& Flora, C.B. (2011). The adaptation coalition toolkit: Building community resilience to climate change. Washington, DC: The World Bank. 
Baltzer, J.L., Veness, T., Chasmer, L.E., Sniderhan, A., \& Quinton, W.L. (2014). Forests on thawing permafrost : Fragmentation, edge effects, and net forest loss. Global Change Biology, 20, 824-834.

Beaumier, M.C., \& Ford, J.D. (2010). Food insecurity among Inuit women exacerbated by socioeconomic stresses and climate change. Canadian Journal of Public Health, 101(3), 196-201.

Bennett, T.D., \& Lantz, T.C. (2014). Participatory photomapping: a method for documenting, contextualizing, and sharing indigenous observations of environmental conditions. Polar Geography, 37(1), 28-47.

Berkes, F. (1999). Sacred ecology: Traditional ecological knowledge and resource management. London: Taylor \& Francis.

Berkes, F., Colding, J., \& Folke, C. (2000). Rediscovery of traditional ecological knowledge as adaptive management. Ecological Applications, 10(5), 1251-1262.

Berkes, F., \& Jolly, D. (2001). Adapting to climate change: Social-ecological resilience in a Canadian western arctic community. Conservation Ecology, 5(2), 18.

Berkes, F., \& Ross, H. (2013). Community resilience: Toward an integrated approach. Society \& Natural Resources, 26(1), 5-20.

Blay-Palmer, A.D., Knezevic, I., Andrée, P., Ballamingie, P., Landman, K.E., Mount, P., Nelson, C.H., Nelson, E., Lori, M, Stroink, M.L., \& Skinner, K. (2013). Future food system research priorities: A sustainable food systems perspective from Ontario, Canada. Journal of Agriculture, Food Systems, and Community Development, 3(4), 227-234.

Blay-Palmer, A., Sonnino, R., \& Custot, J. (2015). A food politics of the possible? Growing sustainable food systems through networks of knowledge. Agriculture and Human Values, 33(1), 27-43.

Bradley, E.H., Curry, L.A., \& Devers, K.J. (2007). Qualitative data analysis for health services research: Developing taxonomy, themes, and theory. Health Services Research, 42(4), 1758-1772.

Chabot, M. (2003). Economic changes, household strategies, and social relations of contemporary Nunavik Inuit. Polar Record, 39(1), 19-34.

Chen, W., Russell, D.E., Gunn, A., Croft, B., Chen, W.R., Fernandes, R., Zhao, H., Li, J., Zhang, Y., Koehler, K., Olthof, I., Fraser, R.H., Leblanc, S.G., Henry, G.R., White, R.G., \& Finstad, G.L. (2013). Monitoring habitat condition changes during winter and pre-calving migration for Bathurst Caribou in northern Canada. Biodiversity, 14(1), 36-44. 
Coleman, K.A., Palmer, M.J., Korosi, J.B., Kokelj, S., Jackson, K., Hargan, K.E., Mustaphi, C.J.C., Thienpont, J.R., Kimpe, L.E., Blais, J.M., Pisaric, M.F.J., \& Smol, J.P. (2015). Tracking the impacts of recent warming and thaw of permafrost peatlands on aquatic ecosystems: A multi-proxy approach using remote sensing and lake sediments. Boreal Environmental Research, 20(3), 363-377.

Collings, P. (2011). Economic strategies, community, and food networks in Ulukhaktok, Northwest Territories, Canada. Arctic, 64(2), 207-219.

Collings, P., Wenzel, G., \& Condon, R.G. (1998). Modern food sharing networks and community integration in the central arctic Canadian. Arctic, 51(4), 301-314.

Condon, R.G., Collings, P., \& Wenzel, G. (1995). The best part of life: Subsistence and economic adaptation adult Inuit males among young. Arctic, 48(1), 31-46.

Connolly-Boutin, L., \& Smit, B. (2016). Climate change, food security, and livelihoods in subSaharan Africa. Regional Environmental Change, 16, 385-399.

Council of Canadian Academies. (2014). Aboriginal food security in Northern Canada: An assessment of the state of knowledge. Ottawa, ON: Council of Canadian Academies.

Cunsolo-Willox, A., Harper, S.L., Ford, J.D., Landman, K., Houle, K., \& Edge, V.L. (2012). "From this place and of this place:” climate change, sense of place, and health in Nunatsiavut, Canada. Social Science \& Medicine, 75(3), 538-547.

Davoudi, S., Brooks, E., \& Mehmood, A. (2013). Evolutionary resilience and strategies for climate adaptation. Planning, Practice and Research, 28(3), 307-322.

Dombrowski, K., Khan, B., Channell, E., Moses, J., Mclean, K., \& Misshula, E. (2013). Kinship, family, and exchange in a Labrador Inuit community. Arctic Anthropology, 50(1), 89-104.

Douglas, V., Chan, H.M., Wesche, S., Dickson, C., Kassi, N., \& Williams, M. (2014). Reconciling traditional knowledge, food security, and climate change: Experience from Old Crow, YT, Canada. Progress in Community Health Partnerships: Research, Education, and Action, 8(1), 21-27.

Egeland, G.M., Johnson-Down, L., Cao, Z.R., Sheikh, N., \& Weiler, H. (2011). Food insecurity and nutrition transition combine to affect nutrient intakes in Canadian Arctic communities. Journal of Nutrition, 25, 1746-1753.

Emery, M., \& Flora, C. (2006). Spiraling-up: Mapping community transformation with community capitals framework. Community Development, 37(1), 19-35.

Flora, C., Flora, J.R., \& Fey, S. (2004). Rural communities: Legacy and change (2nd ed.). Boulder, CO: Westview Press. 
Ford, J.D., Pearce, T., Duerden, F., Furgal, C., \& Smit, B. (2010). Climate change policy responses for Canada's Inuit population: The importance of and opportunities for adaptation. Global Environmental Change, 20, 177-191.

Ford, J.D., \& Smit, B. (2004). A framework for assessing the vulnerability of communities in the Canadian Arctic to risks associated with climate change. Arctic, 57(4), 389-400.

Ford, J.D., Smit, B., \& Wandel, J. (2006a). Vulnerability to climate change in the Arctic: A case study from Arctic Bay, Canada. Global Environmental Change, 16(2), 145-160.

Ford, J.D., Smit, B., Wandel, J., Allurut, M., Shappa, K., Ittusarjuat, H., \& Qrunnut, K. (2008). Climate change in the Arctic: current and future vulnerability in two Inuit communities in Canada. The Geographical Journal, 174(1), 45-62.

Ford, J.D., Smit, B., Wandel, J., \& MacDonald, J. (2006b). Vulnerability to climate change in Igloolik, Nunavut: What we can learn from the past and present. Polar Record, 42(2), 127.

Fresque-Baxter, J.A. (2013). Participatory photography as a means to explore young people's experiences of water resource change. Indigenous Policy Journal, 23(4), 1-17.

Furgal, C., \& Seguin, J. (2006). Climate change, health and vulnerability in Canadian Northern Aboriginal communities. Environmental Health Perspectives, 114(12), 1964-1970.

Gagne, D., Blanchet, R., Lauziere, J., Vaissiere, E., Vezina, C., Ayotte, P., Dery, S., \& O’Brien, H.T. (2012). Traditional food consumption is associated with higher nutrient intakes in Inuit children attending childcare centres in Nunavik. International Journal of Circumpolar Health, 71, 1-9.

Gill, H., Lantz, T., \& Gwich’in Social and Cultural Institute. (2014). A community-based approach to mapping Gwich' in observations of environmental changes in the lower Peel River watershed, NT. Journal of Ethnobiology, 34(3), 294-314.

Gilmore, T., Krantz, J., \& Ramirez, R. (1986). Action based modes of inquiry and the hostresearcher relationship. Consultation, 5(3), 160-176.

Guyot, M., Dickson, C., Paci, C., Furgal, C., \& Chan, H.M. (2006). Local observations of climate change and impacts on traditional food security in two northern Aboriginal communities. International Journal of Circumpolar Health, 65(5), 403-415.

GWNT. (2015). Growing forward 2. Retrieved from http://www.iti.gov.nt.ca/programsservices/growing-forward.

Harder, M.T. \& Wenzel, G.W. (2012). Inuit subsistence, social economy and food security in Clyde River, Nunavut. Arctic, 65(3), 305-318.

Hay, I. (Ed.). (2000). Qualitative research methods in human geography. United Kingdom: Oxford University Press. 
Helm, J. (2002). The people of Denendeh: Ethnohistory of the Indians of Canada's Northwest Territories. Montreal: Mcgill Queens University Press.

Hipel, K.W., Fang, L., \& Heng, M. (2010). System of systems approach to policy development for global food security. Journal of Systems Science and Systems Engineering, 19(1), 1-21.

IPCC. (2014). Climate change 2014: Impacts, adaptation, and vulnerability. Part B: Regional aspects. Contribution of working wroup II to the fifth assessment report of the intergovernmental panel on climate change. In V.R. Barros, C.B. Field, D.J. Dokken, M.D. Mastrandrea, K.J. Mach, T.E. Bilir, M. Chatterjee, K.L. Ebi, Y.O. Estrada, R.C. Genova, B. Girma, E.S. Kissel, A.N. Levy, S. MacCracken, P.R. Mastrandrea, \& L.L. White. (Eds.). United Kingdom: Cambridge University Press.

Johnson-Down, L., \& Egeland, G.M. (2010). Adequate nutrient intakes are associated with traditional food consumption in nunavut inuit children aged 3-5 years. The Journal of Nutrition, 140(7), 1311-1316.

Kofinas, G.P., Chapin, F.S., BurnSilver, S.B., Schmidt, J.I., Fresco, N.L., Kielland, K., Martin, S., Springsteen, A., \& Rupp, T.S. (2010). Resilience of Athabascan subsistence systems to interior Alaska’s changing climate. Canadian Journal of Forest Research, 40(7), 1347-1359.

Kuhnlein, H.V., \& Receveur, O. (1996). Dietary change and traditional food systems of indigenous peoples. Annual review of nutrition, 16, 417-442.

Kuhnlein, H.V., \& Receveur, O. (2007). Local cultural animal food contributes high levels of nutrients for Arctic Canadian Indigenous adults and children. The Journal of Nutrition, 137(4), 1110-1114.

Kuhnlein, H.V., Receveur, O., Soueida, R., \& Egeland, G.M. (2004). Community and international nutrition Arctic Indigenous peoples experience the nutrition transition with changing dietary patterns and obesity. Journal of Nutrition, 134(6), 1447-1453.

Lambden, J., Receveur, O., \& Kuhnlein, H.V. (2007). Traditional food attributes must be included in studies of food security in the Canadian Arctic. International Journal of Circumpolar Health, 66(4), 308-319.

Levine, S., Chastre, C., Ntububa, S., MacAskill, J., LeJeune, S., Guluma, Y., Acidri, J., \& Kirkwood, A. (2004). Missing the point: An analysis of food security interventions in the Great Lakes. United Kingdom: Humanitarian Practice Network.

Loring, P.A. \& Gerlach, S.C. (2009). Food, culture, and human health in Alaska: an integrative health approach to food security. Environmental Science \& Policy, 12(4), 466-478. 
Loring, P.A., \& Gerlach, S.C. (2010). Outpost gardening in interior Alaska: Food system innovation and the Alaska Native gardens of the 1930s through the 1970s. Ethnohistory, 57(2), 183-199.

Marsden, T. (2012). Food systems under pressure: regulatory instabilities and the challenge of sustainable development. In G. Spaargaren, P. Oosterveer, \& A. Loeber (Eds.). Food practices in transition: changing food consumption, retail and production in the age of reflexive modernity. New York: Routledge.

Mays, N. \& Pope, C. (1995). Qualitative research observational methods in health care settings. British Medical Journal, 311, 182-184.

McGregor, D., Bayha, W., \& Simmons, D. (2010). “Our responsibility to keep the land alive”: Voices of Northern Indigenous researchers. Pimatisiwin: A Journal of Aboriginal and Indigenous Community Health, 8(1), 101-124.

McMillan, R. \& Parlee, B. (2013). Dene hunting organization in Fort Good Hope, Northwest Territories: "Ways we help each other and share what we can.” Arctic, 66(4), 435-447.

McTaggart, R. (1999). Reflection on the purposes of research, action, and scholarship: A case of cross-cultural participatory action research. Systemic Practice and Action Research, 12(5), 493-511.

Minkler, M., \& Wallerstein, N. (Eds.). (2011). Community-based participatory research for health: From process to outcomes. San Francisco, CA: John Wiley \& Sons.

Nickels, S., Furgal, C., Buell, M., \& Moquin, H. (2006). Unikkaaqatigiit-putting the human face on climate change: perspectives from Inuit in Canada. Inuit Tapiriit Kanatami, Nasivvik Centre for Inuit Health and Changing Environments at Universite Laval; Ajunnginiq Centre. Ottawa: National Aboriginal Health Organization.

Nkem, J.N., Somorin, O.A., \& Sonwa, D.J. (2013). Profiling climate change vulnerability of forest indigenous communities in the Congo Basin, Mitigation and Adaptation Strategies for Global Change, 18(5), 513-533.

Northwest Territories Bureau of Statistics. (2013). Summary of NWT Community Statistics. Yellowknife, NT.

NWT Protected Area Strategy Advisory Committee. (1999). The Northwest Territories Protected Areas Strategy: A Balanced Approach to Establishing Protected Areas in the Northwest Territories.

Parlee, B., Manseau, M., \& Lutsel K’é Dene First Nation. (2005). Using traditional knowledge to adapt to ecological change : Denésôåiné monitoring of caribou movements. Arctic, 58(1), 26-37. 
Parlee, B., Neil, J.O., \& Lutsel K’e Dene First Nation. (2007). “The Dene Way of Life”: Perspectives on health from Canada's North. Journal of Canadian Studies, 41(3), 112-133.

Pearce, T.D., Ford, J.D., Laidler, G.J., Smit, B., Duerden, F., Allarut, M., Andrachuk, M., Baryluk, S., Dialla, A., Elee, P., Goose, A., Ikummaq, T., Joamie, E., Kataoyak, F., Loring, E., Meakin, S. Nickels, S., Shappa, K., Shirley, J., \& Wandel, J. (2009a). Community collaboration and climate change research in the Canadian Arctic. Polar Research, 28(1), $10-27$.

Pearce, T., Ford, J.D., Caron, A., \& Kudlak, B.P. (2012). Climate change adaptation planning in remote, resource-dependent communities: an Arctic example. Regional Environmental Change, 12(4), 825-837.

Pearce, T., Ford, J., Willox, A.C., \& Smit, B. (2015). Inuit traditional ecological knowledge (TEK ), subsistence hunting and adaptation to climate change in the Canadian Arctic. Arctic, 68(2), 233-245.

Pearce, T., Smit, B., Duerden, F., Ford, J.D., Goose, A., \& Kataoyak, F. (2009b). Inuit vulnerability and adaptive capacity to climate change in Ulukhaktok, Northwest Territories, Canada. Polar Record, 46(2), 157-177.

Penn, H.J.F., Gerlach, S.C., \& Loring, P.A. (2016). Seasons of stress: Understanding the Dynamic nature of people's ability to respond to change and surprise. Weather, Climate, and Society, 8(4), 435-446.

Popkin, B.M. (2002). The shift in stages of the nutrition transition in the developing world differs from past experiences. Public health nutrition, 5, 205-214.

Power, E.M. (2008). Conceptualizing food security for Aboriginal people in Canada. Canadian Journal of Public Health, 99(2), 95-97.

Price, D.T., Alfaro, R.I., Brown, K.J., Flannigan, M.D., Fleming, R.A., Hogg, E.H., Girardin, M.P., Lakusta, T., Johnston, M., Mckenney, D.W., Pedlar, J.H., Stratton, T., Sturrock, R.N., Thompson, I.D., Trofymow, J.A. \& Venier, L.A. (2013). Anticipating the consequences of climate change for Canada's Boreal forest ecosystems. Environmental Review, 21, 322-365.

Prowse, T.D., Furgal, C., Chouinard, R., Melling, H., Milburn, D., \& Smith, S.L. (2009). Implications of climate change for economic development in northern Canada: energy, resource, and transportation sectors. Ambio, 38(5), 272-281.

Putnam, R.D. (1995). Bowling alone: America's declining social capital. Journal of Democracy, 6, 65-78. 
Quinton, W.L., Hayashi, M., \& Chasmer, L.E. (2011). Permafrost-thaw-induced land-cover change in the Canadian subarctic: Implications for water resources. Hydrological Processes, 25(1), 152-158.

Receveur, O., Boulay, M., \& Kuhnlein, H.V. (1997). Community and international nutrition decreasing traditional food use affects diet quality for adult Dene /Métis in 16 communities of the Canadian Northwest Territories. Journal of Nutrition, 127(11), 2179-2186.

Rosol, R., Huet, C., Wood, M., Lennie, C., Osborne, G., \& Egeland, G. M. (2011). Prevalence of affirmative responses to questions of food insecurity: International Polar Year Inuit Health Survey, 2007-2008. International Journal of Circumpolar Health, 70(5), 488-497.

Ross, H. \& Berkes, F. (2014). Research approaches for understanding, enhancing, and monitoring community resilience. Society \& Natural Resources, 27(8), 787-804.

Scoones, I. (1998). Sustainable rural livelihoods: A framework for analysis. Working Paper 72. Brighton, UK: Institute for Development Studies.

Scoones, I. (2009). Livelihoods perspectives and rural development. Journal of Peasant Studies, 36(1), 171-196.

Skinner, K., Hanning, R.M., Desjardins, E., \& Tsuji, L.J.S. (2013). Giving voice to food insecurity in a remote indigenous community in subarctic Ontario, Canada: Traditional ways, ways to cope, ways forward. BMC Public Health, 13, 427.

Smit, B., \& Wandel, J. (2006). Adaptation, adaptive capacity and vulnerability. Global Environmental Change, 16(3), 282-292.

Stone, M.T., \& Nyaupane, G.P. (2015). Protected areas, tourism and community livelihoods linkages: A comprehensive analysis approach. Journal of Sustainable Tourism, 24(5), 673-693.

Stroink, M.L. \& Nelson, C.H. (2013). Complexity and food hubs: Five case studies from Northern Ontario. Local Environment, 18(5), 620-635.

Tarasuk, V., Mitchell, A., \& Dachner, N. (2016). Household food insecurity in Canada, 2014 PROOF, Research to Identify Policy Options to Reduce Food Insecurity.

Tondu, J.M.E., Balasubramaniam, A.M., Chavarie, L., Gantner, N., Knopp, J.A., Provencher, J.F., Wong, Y., \& Simmons, D. (2014). Working with Northern communities to build collaborative research partnerships: Perspectives from early career researchers. Arctic, 67(3), 419-429.

Wakegijig, J., Osborne, G., Statham, S., \& Issaluk, M.D. (2013). Collaborating toward improving food security in Nunavut. International Journal of Circumpolar Health, 72, 1-8. 
Wallerstein, N. \& Bernstein, E. (1994). Introduction to community empowerment, participatory education, and health. Health Education Quarterly, 21(2), 141-148.

Wesche, S.D. \& Chan, H.M. (2010). Adapting to the impacts of climate change on food security among Inuit in the Western Canadian Arctic. EcoHealth, 7(3), 361-373.

Williams, T.J., Quinton, W.L., \& Baltzer, J.L. (2013). Linear disturbances on discontinuous permafrost: implications for thaw-induced changes to land cover and drainage patterns. Environmental Research Letters, 8, 1-12.

Wolfe, B.B., Humphries, M.M., Pisaric, M.F.J., Balasubramaniam, A.M., Burn, C.R., Chan, L., Froese, D.G., Graupe, S., Hall, R.I., Lantz, T, Porter, T.J., Roy-leveillee, P., \& Turner, K.W. (2011). Environmental change and traditional use of the Old Crow Flats in Northern Canada: An IPY opportunity to meet the challenges of the new northern research paradigm. Arctic, 64(1), 127-135. 